\title{
A QT-intervallum rövidtávú variabilitásának fokozódása elöre jelzi a ciszaprid indukálta kamrai ritmuszavarok kialakulását
}

\author{
Krajcs Nóra',2, Tábori Katalin', Juhász Viktor', Hornyik Tibor', Varró András ${ }^{1,3}$, \\ Baczkó István
}

\author{
${ }^{1}$ Szegedi Tudományegyetem, Farmakológiai és Farmakoterápiai Intézet, Szeged \\ ${ }^{2}$ MTA, Ökológiai Kutatóközpont, BLI Kísérletes Állattani Osztály, Tihany \\ ${ }^{3}$ MTA-SZTE, Keringésfarmakológiai Kutatócsoport, Szeged
}

Levelezési cím: Dr. Baczkó István, 6720 Szeged, Dóm tér 12. E-mail: baczko.istvan@med.u-szeged.hu

\begin{abstract}
Célkitüzés: A preklinikai gyógyszerbiztonsági tesztek egészséges állatokon, szöveteken vizsgálják a jelölt molekulák szívizom repolarizáció nyújtó hatását, melyek nem képviselik a ritmuszavarok kialakulására fokozott érzékenységet mutató betegeket, és a repolarizáció megnyúlásának mértéke nem korrelál a ritmuszavarok kialakulásának gyakoriságával. Így a fejlesztés alatt álló gyógyszerek proaritmiás mellékhatásainak megbízható előrejelzése várat magára. Vizsgáltuk egy proaritmiás hatásai miatt forgalomból kivont szer, a ciszaprid kamrai ritmuszavarokat kiváltó, valamint EKG paraméterekre kifejtett hatásait szűkített repolarizációs rezervvel rendelkező nyúlmodellen.

Módszerek: Altatott nyulakon a szívizom repolarizációs tartalékot az $\mathrm{I}_{\mathrm{ks}}$-áram farmakológiai gátlásával $(0,1 \mathrm{mg} / \mathrm{kg}$ HMR1556, iv.) csökkentettük. Vizsgáltuk a ciszaprid (0,5, 1 és $2 \mathrm{mg} / \mathrm{kg}$ ), valamint a HMR1556 és ciszaprid kombináció után a ritmuszavarok megjelenését, a hagyományos EKG-intervallumok ( $P Q, R R, Q T$ és $Q T_{c}$ ) mellett meghatároztuk a $Q T$ és RR rövidtávú variabilitását $\left(\mathrm{STV}_{\mathrm{QT}}\right.$ és $\left.\mathrm{STV} \mathrm{V}_{\mathrm{RR}}\right)$. Az STV $\mathrm{ST}_{\mathrm{QT}}$ a ritmuszavarok elörejelzésére javasolt EKG-paraméter.

Eredmények: $\mathrm{Az} \mathrm{IK}_{\mathrm{s}}$-gátló HMR1556 nem okozott ritmuszavarokat, nem nyújtotta a $\mathrm{QT}_{\mathrm{c}}$-t és nem növelte az $\mathrm{STV}_{\mathrm{QT}} \mathrm{-t}$. $\mathrm{A}$ ciszaprid önmagában is okozott ritmuszavarokat, azonban az $\mathrm{I}_{\mathrm{Ks}}$-gátlóval kombinációban jelentösen fokozta a Torsades de Pointes (TdP) ritmuszavar incidenciáját (50\%). A ciszaprid önmagában és HMR1556-al kombinációban hasonlóan nyújtotta a $\mathrm{QT}_{\mathrm{c}}$-t, de az STV $\mathrm{QT}_{\mathrm{T}}$ kifejezett emelkedése a legnagyobb gyakoriságú TdP aritmia mellett jelentkezett.

Következtetések: Csökkent repolarizációs rezerv mellett a ciszaprid fokozta a kamrai aritmiák gyakoriságát, a fokozott ritmuszavar incidenciát a QT-intervallum rövidtávú variabilitásának szignifikáns emelkedése előzte meg. Eredményeink támogatják a proaritmiás kockázat felmérésére során az $\mathrm{STV}_{\mathrm{QT}}$-paraméter meghatározását.
\end{abstract}

Kulcsszavak: repolarizációs tartalék, proaritmia, rövidtávú QT-intervallum variabilitás, Torsades de Pointes, ciszaprid

Increased short-term variability of the QT interval predicts cisapride induced ventricular arrhythmias

Aims: Preclinical drug safety tests employ healthy animals and animal tissues for the investigation of the cardiac repolarization prolonging effects of compounds, that do not represent patients exhibiting increased arrhythmia susceptibility, and the degree of repolarization prolongation does not correlate directly with the incidence of arrhythmias. Therefore, the reliable prediction of proarrhythmic potency of compounds is lacking. Here we investigated the effects of cisapride, a drug withdrawn from the market due to its proarrhythmic side effects, on ventricular arrhythmias and ECG parameters in a rabbit model with impaired repolarization reserve.

Methods: In anaesthetized rabbits, cardiac repolarization reserve was reduced by pharmacological block of the $I_{\mathrm{Ks}}$ current $(0.1 \mathrm{mg} / \mathrm{kg}$ HMR1556, i.v.). The development of arrhythmias was registered following cisapride $(0.5,1 \mathrm{and} 2 \mathrm{mg} / \mathrm{kg})$ or HMR1556 and cisapride combination ( $n=10$ in all groups). Conventional ECG intervals (PQ, RR, $Q T$ and $\left.Q T_{c}\right)$, the short term variability of $Q T$ and $R R\left(S T V_{Q T}\right.$ and $\left.S T V_{R R}\right)$ were measured. STV $V_{Q T}$ is an ECG parameter suggested for more reliable prediction of arrhythmias.

Results: The $\mathrm{I}_{\mathrm{KS}}$ blocker HMR1556 did not cause any arrhythmias, did not prolong the $\mathrm{QT}_{\mathrm{C}}$ and did not increase $\mathrm{STV} \mathrm{V}_{\mathrm{QT}}$. Cisapride induced some arrhythmias, however, the incidence of Torsades de Pointes (TdP) was markedly increased (50\%) when cisapride was combined with the $I_{\mathrm{Ks}}$ blocker. Cisapride alone and with HMR1556 in combination caused similar QT, prolongation. The STV $\mathrm{QT}_{\mathrm{T}}$ was highest following the combination that caused the highest incidence of TdP.

Conclusions: In a rabbit model with reduced repolarization reserve, cisapride increased the incidence of ventricular arrhythmias and the significant elevation of the short term variability of the QT interval preceded the increase in arrhythmia incidence. Our results support the calculation of STV ${ }_{\mathrm{QT}}$ during proarrhythmic side effect assessment.

Keywords: repolarization reserve, proarrhythmia, short term variability of the QT interval, Torsades de Pointes, cisapride 


\section{Bevezetés}

A gyógyszer indukálta, életet veszélyeztető kamrai ritmuszavar a hatóanyagok legaggasztóbb és legsúlyosabb mellékhatásai közé tartozik. Ahhoz, hogy megakadályozzuk az új gyógyszerjelöltek igen költséges fejlesztése során a lemorzsolódást, valamint a már forgalomba hozott gyógyszerek visszavonását proaritmiás hatásaik miatt, a hatóanyagok ritmuszavart kiváltó potenciáljának preklinikai és klinikai felmérésén javítanunk kell (1). Számos kardiovaszkuláris és nem kardiovaszkuláris szer okozhat ún. Torsades de Pointes (TdP) kamrai ritmuszavart (2). A TdP tipikusan (de nem kizárólag) gyógyszer-indukálta kaotikus kamrai tachycardia, amely sokszor spontán megszünik, ilyenkor rövid ideig tartó eszméletvesztés jelentkezhet, de a TdP átmehet kamrafibrillációba és hirtelen szívhalált okozhat (3). Elfogadhatatlan, hogy a nem életveszélyes kórállapotok kezelésére használt szerek alkalmazása egyes esetekben hirtelen szívhalálhoz vezethet, de fontos kiemelni, hogy klinikai körülmények között rendkívül nehéz a TdP-ritmuszavar megbízható elörejelzése (3). Meglepő, de a jelenlegi nemzetközi irányelvekben foglalt, kísérleti állatokon és azokból származó izolált szíveken, szívizomszöveten, sejteken végzett preklinikai, szív-elektrofiziológiai biztonsági vizsgálatok egészséges állatok felhasználásával történik (4), a humán EKG-szürővizsgálatok pedig egészséges önkénteseken zajlanak (5). Számos kórkép jár a szív repolarizáció zavaraival és a repolarizációs rezerv károsodásával (6), ezekben a betegekben jóval magasabb a kamrai ritmuszavarok kialakulásának rizikója (pl. krónikus szívelégtelenség, hipertrófiás cardiomyopathia, kongenitális hosszú QT-szindrómák, diabetes mellitus stb.). Könnyű belátni, hogy az egészséges, strukturális és/vagy elektromos szívizom-átépüléssel (ún. „remodelling”) nem rendelkező állatmodellek, valamint az egészséges önkéntesek nem reprezentálják megfelelően a szívritmuszavarok kialakulására különösen érzékeny betegpopulációt. Továbbá, az említett vizsgálatok a gyógyszerjelölt molekulák hERG-áramgátló, szívizom szöveti akciós potenciált és az EKG-n mérhető QT-intervallumot nyújtó hatásokra koncentrálnak. Egyre több irodalmi adat igazolja ugyanakkor, hogy a szívizom-repolarizációt nyújtó hatás önmagában nem tehető egyenlővé a fokozott proaritmiás kockázattal $(7,8,9,10)$. Számos kórkép járhat a szívizom akciós potenciál felszálló ágának lassulásával és következményes vezetési zavarral, amely szintén elösegíti a kamrai ritmuszavarok kialakulását (11). A fenti megfontolások alapján a jelenlegi modellek alkalmazá- sával rejtve maradhat a fejlesztés alatt álló hatóanyagok valódi proaritmiás potenciálja, így szükség van új, a ritmuszavarok iránt fokozott érzékenységet mutató betegcsoportokat jobban jellemző kísérletes modellek bevezetésére.

Munkacsoportunk a korábbiakban kifejlesztett egy nyúl proaritmia kísérleti modellt, amelyben a repolarizációs tartalék $(6,12)$ szükítését az abban kulcsszerepet játszó, késői egyenirányító káliumáram lassú komponenseként $\left(I_{K s}\right)$ számon tartott repolarizáló áram $(13,14)$ akut farmakológiai gátlásával értük el (15). A hagyományos modellekkel szemben ez a kísérleti elrendezés jobban reprodukálhatja a patológiás okokból meggyengült repolarizációs tartalék talaján megemelkedett kamrai ritmuszavarok iránti érzékenységet (16).

Jelen kísérleteink célja az volt, hogy a fenti modellben megvizsgáljuk a ciszaprid, egy proaritmiás mellékhatásai miatt számos országban a gyógyszerforgalomból kivont prokinetikum kamrai ritmuszavarokra, hagyományos EKG-paraméterekre, valamint a közelmúltban a súlyos kamrai ritmuszavarok megbízhatóbb előrejelzésére javasolt nem konvencionális EKG-paraméterre, a QT-intervallum rövidtávú variabilitására $\left(\mathrm{STV}_{\mathrm{QT}}\right)$ kifejtett hatásait.

\section{Módszerek}

\section{Torsades de Pointes proaritmia modell altatott nyulakon}

Kísérleti protokolljainkat a Szegedi Tudományegyetem Munkahelyi Állatkísérletes Bizottsága (engedély száma: 1-74-5/2012) és a Csongrád Megyei Kormányhivatal Élelmiszerlánc Biztonsági és Állategészségügyi Igazgatósága engedélyezte (engedély száma: XIII/1211/2012).

A kísérleteket hím, 2-3 kg tömegű új-zélandi fehér nyulakon végeztük. Az állatokat a jobb fül marginális vénájába helyezett kanülön át tiopentállal $(50 \mathrm{mg} / \mathrm{kg})$ altattuk, vérnyomásmérés céljából a bal arteria carotist, későbbi anyagbeadáshoz a jobb vena jugularist kanüláltuk. A beavatkozás után 20 perces stabilizálódási idő elteltével kezdtük meg a méréseket. A kísérlet végén a nyulakat $300 \mathrm{mg} / \mathrm{kg}$ pentobarbitál (RELEASE) intravénás beadásával altattuk túl. $A z$ artériás vérnyomást és az elektrokardiogramot (I-III. elvezetés) a kísérlet időtartama alatt folyamatosan regisztráltuk, digitalizáltuk és tároltuk a későbbi „off-line” elemzéshez SPEL Haemosys Advanced szoftver segítségével (3.2 verzió, MDE Heidelberg, Németország). A PQ,- RR-, QT-intervallumokat 30 egymást követő ütés átlagaként számoltuk (egy intervallum rövidtávú variabilitásának számításához

\section{Rövidítések jegyzéke}

ES: extrasystole; $I_{\mathrm{Ca}, \mathrm{L}}$ : L-típusú kalciumáram; $\mathrm{I}_{\mathrm{Kr}}$ : késői egyenirányító káliumáram gyors komponense; $I_{\mathrm{Ks}}$ : késői egyenirányító káliumáram lassú komponense; $I_{\text {to }}$ : tranziens kifelé haladó káliumáram; MBP: artériás középnyomás; $\mathrm{QT}_{\mathrm{c}}$ : frekvencia korrigált QT-intervallum; STV $\mathrm{QT}_{\mathrm{T}}$ : a QT-intervallum rövidtávú variabilitása; STV $\mathrm{RR}_{\mathrm{R}}$ : az RR-intervallum rövidtávú variabilitása TdP: Torsades de Pointes kamrai tachycardia; VT: kamrai tachycardia. 
szükséges minimális ütésszám). A QT-intervallumok méréséhez a Farkas és munkatársai által megadott irányelveket követtük (17). Mivel a nyulak jóval magasabb szívfrekvenciája miatt az embernél használatos formulák nem tükrözik a QT-intervallum frekvenciafüggő változásait, a QT-intervallumok frekvencia korrekcióját korábban publikált, altatott nyulakra kidolgozott egyenlettel számítottuk: $\quad \mathrm{QT}_{\mathrm{c}}=\mathrm{QT}-\left(0,704^{*}[\mathrm{RR}-250]\right)$ (18). A kísérletesen előidézett kamrai ritmuszavarok osztályozásánál a korszerűsített Lambeth Konvenció alapelveit követtük: pl. a kettő vagy három egymást követő kamrai extrasystole esetén az aritmiát „Salvo”-ként definiáltuk (19).

\section{Az RR - és QT-intervallum rövidtávú variabilitása (STV $V_{R R}$ és STV $V_{Q T}$ )}

Az RR- és QT-intervallumok ütésről ütésre számított instabilitásának jellemzésére ún. Poincaré ábrázolást végeztünk, ahol az RR- és QT-intervallumokat a megelőző intervallumértékek függvényében ábrázoltuk ( 2 . ábra). A Poincaré-diagramok 30 egymást követő, sinusritmusban mért intervallum eredményeit mutatják be. Ha az adott kísérleti időpontban TdP-ritmuszavar

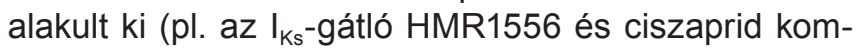
binációját követően), akkor a mérést a TdP kialakulása előtt végeztük el. Az STV $V_{R R}$ és $S T V_{Q T}$ számításához a következő egyenletet használtuk: STV $=\sum\left|D_{n+1}-D_{n}\right|$ $(30 * \sqrt{ } 2)-1$, ahol a D a QT- vagy RR-intervallumot képviseli. Az intervallumok instabilitásának karakterizálása a Poincaré-térkép kvalitatív és kvantitatív matematikai analízisén alapszik (20).

\section{Felhasznált anyagok és adagolás}

Az $\mathrm{I}_{\mathrm{Ks}}$-gátló HMR1556 (Tocris Bioscience, Abingdon, Egyesült Királyság) és a ciszaprid (Sigma Aldrich Hungary, Budapest) oldása dimetil-szulfoxidban (DMSO; végső beadott koncentráció $<0,1 \%$ ) történt. A törzsoldatok hígítása közvetlenül a kísérleteket megelőzően történt.

Minden intravénás infúzió programozható infúziós pumpával történt (Terufusion TE-3, Terumo Europe, Leuven, Belgium). A nyulak első csoportja 0,5, 1 és 2 $\mathrm{mg} / \mathrm{kg}$ ciszaprid infúziót kapott, minden dózist 5 perc alatt, $2 \mathrm{ml} / \mathrm{kg}$ volumenben. A dózisok beadása között 20 perc telt el folyamatos vérnyomás és EKG-regisztrálás mellett. A második csoport $0,1 \mathrm{mg} / \mathrm{kg} \mathrm{I} \mathrm{I}_{\mathrm{Ks}}$-gátló HMR1556-ot kapott, amelyet 20 perc elteltével a fentiekben említett 0,5, 1 majd $2 \mathrm{mg} / \mathrm{kg}$ ciszaprid infúzió követett.

\section{Statisztikai analízis}

A ritmuszavarok előfordulási gyakoriságának összehasonlítására a x2-tesztet alkalmaztuk Yates-korrekcióval. Minden más értéket átlag $\pm S E M$ formában tüntettünk fel. Variancianalízis után a csoportokat Student t-teszt segítségével hasonlítottuk össze. A statisztikai szignifikancia elfogadott határértéke $p<0,05$ volt.
1. TÁBLÁZAT. A szívfrekvencia, QT- és $\mathrm{QT}_{c}$-intervallum, valamint az artériás középnyomás (MBP) kiindulási értékei a két vizsgálati csoportban (kezelések előtt) ( $n=10$ állat/csoport)

\begin{tabular}{|l|c|l|l|l|}
\hline & $\begin{array}{l}\text { Szívfrek- } \\
\text { vencia } \\
\text { (1/perc) }\end{array}$ & $\begin{array}{l}\text { QT-inter- } \\
\text { vallum } \\
\text { (msec) }\end{array}$ & $\begin{array}{l}\mathbf{Q T}_{\text {c-in- }} \text { tervallum } \\
\text { (msec) }\end{array}$ & $\begin{array}{l}\text { MBP } \\
\text { (Hgmm) }\end{array}$ \\
\hline $\begin{array}{l}\text { 1. csoport } \\
\text { (ciszaprid) }\end{array}$ & $268 \pm 11,5$ & $151,2 \pm 6,66$ & $166,9 \pm 6,00$ & $87 \pm 4,1$ \\
\hline $\begin{array}{l}\text { 2. csoport } \\
\text { (HMR+ci- } \\
\text { szaprid) }\end{array}$ & $273 \pm 10,7$ & $146,7 \pm 6,93$ & $164,9 \pm 2,32$ & $84 \pm 4,1$ \\
\hline
\end{tabular}

\section{Eredmények}

A ciszaprid, az I Ks $_{\text {-gátló HMR } 1556 \text { és }}$ kombinációjuk hatása az artériás középnyomásra, a szívfrekvenciára, a PQ- és a QT,-intervallumra altatott nyulakon Az altatott nyulak két csoportja között a kezelések megkezdése előtt nem mutatkozott különbség az artériás középnyomás, a szívfrekvencia, QT- és QT $T_{c}$-értékek tekintetében (1. táblázat). A vérnyomásértékek a két csoportban a kezelések következtében nem változtak szignifikánsan.

A szívfrekvenciát szignifikánsan csökkentette (RR-intervallum nőtt) a ciszaprid mindhárom dózisa, míg az I $_{\text {Ks }}$-gátló HMR1556 nem volt hatással a szívfrekvenciára (1. ábra, bal panel). A várakozásoknak megfelelően (ismert $\mathrm{I}_{\mathrm{Kr}}$-gátló hatása alapján) a frekvencia korrigált QT-intervallumot (QT $)$ a ciszaprid 1 és $2 \mathrm{mg} / \mathrm{kg}$ dózisban nyújtotta, a HMR1556 önmagában nem nyújtotta a repolarizációt altatott nyulakon (1. ábra, jobb panel).

A PQ-intervallumok alapértékei nem különböztek a két csoportban $(64,9 \pm 3,27$ vs. $63,2 \pm 2,06 \mathrm{~ms},(n=10)$ mindkét csoportban, $p>0,05)$. A ciszaprid legnagyobb dózisa szignifikánsan nyújtotta a $\mathrm{PQ}$-intervallumot, amely a ciszaprid nagyobb dózisban korábban tapasztalt kalciumcsatorna-gátló hatásával összhangban áll (74,8 $\pm 3,75$ vs. $64,9 \pm 3,27$ ms kontrollban, $p<0,05)$.

A ciszaprid, az I Ks-gátló HMR 1556 és

kombinációjuk hatása a rövidtávú RR-,

QT-variabiltásra, valamint a kamrai ritmuszavarok incidenciájára altatott nyulakon

A szívizom kamrai repolarizáció temporális instabilitását jellemző rövidtávú QT-intervallum variabilitás $\mathrm{I}_{\mathrm{Ks}}$-gátlást, valamint HMR1556+ciszaprid kombináció adagolását követő illusztrálására Poincaré-diagramot szerkesztettünk, amely egy altatott nyúlon mutatja be a jellemző STV ${ }_{Q T}$-változásokat kísérleti elrendezésünkben (2. ábra). Látható, hogy a kontroll QT-variabilitáshoz képest (fekete körök) az I Is -gátló HMR1556 (szürke négyzetek) nem változtatott az STV $\mathrm{QT}-\mathrm{n}$, míg a ciszaprid HMR1556-ot követő adagolása után az adatpontok által (világosszürke háromszögek) lefedett terület jelentősen megnőtt, illusztrálva a megemelkedett STV $\mathrm{QT}_{\mathrm{T}}$-értékét, míg az adatponthalmaz jobbra és 


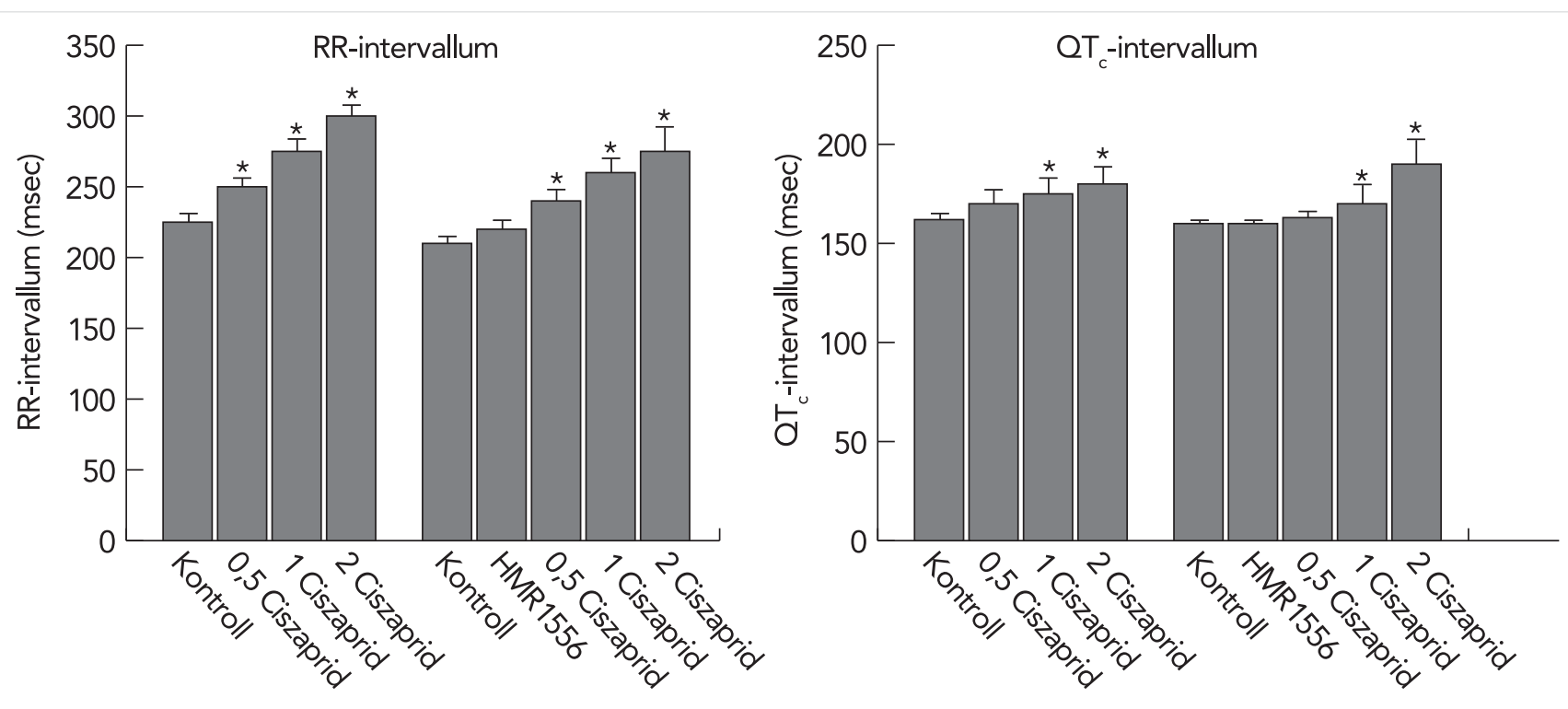

1. ÁBRA. A ciszaprid (0,5-1, és $2 \mathrm{mg} / \mathrm{kg})$ hatása önmagában, valamint $\mathrm{I}_{\mathrm{Ks}}$-gátló HMR1556 $(0,1 \mathrm{mg} / \mathrm{kg})$ elökezelést követően az RR- és $\mathrm{QT}_{\mathrm{c}}$-intervallumokra altatott nyúlon. $\mathrm{n}=10$ mindkét csoportban; ${ }^{\star} \mathrm{p}<0,05$ a kontrollhoz képest

felfelé tolódott el a ciszaprid QT-intervallumot nyújtó hatását jelezve (2. ábra).

Felmerülhet, hogy a QT-intervallum variabilitását befolyásolhatja a szívfrekvencia rövidtávú variabilitása is, ezért számítottuk és ábrázoltuk az $\mathrm{STV}_{\mathrm{RR}}$-értékeket is a két vizsgált csoportban (3. ábra. bal panel). A ciszaprid legnagyobb alkalmazott dózisa szignifikánsan növelte az STV $\mathrm{RR}-\mathrm{t}$, míg HMR1556 előkezelést követően az 1 és $2 \mathrm{mg} / \mathrm{kg}$ dózisú ciszaprid fokozta az STV $\mathrm{RR} \mathrm{t}$ (3. ábra, bal panel). Látható azonban, hogy az STV $\mathrm{RR}^{-n o ̈-}$ vekedés mértéke, valamint a növekedés megléte vagy hiánya nem mutatott összefüggést az STV $\mathrm{QT}_{\mathrm{T}}$ változásaival (3. ábra, jobb panel). A repolarizáció instabilitását jellemző $S T V_{Q T}$ minden ciszaprid kezelést követően

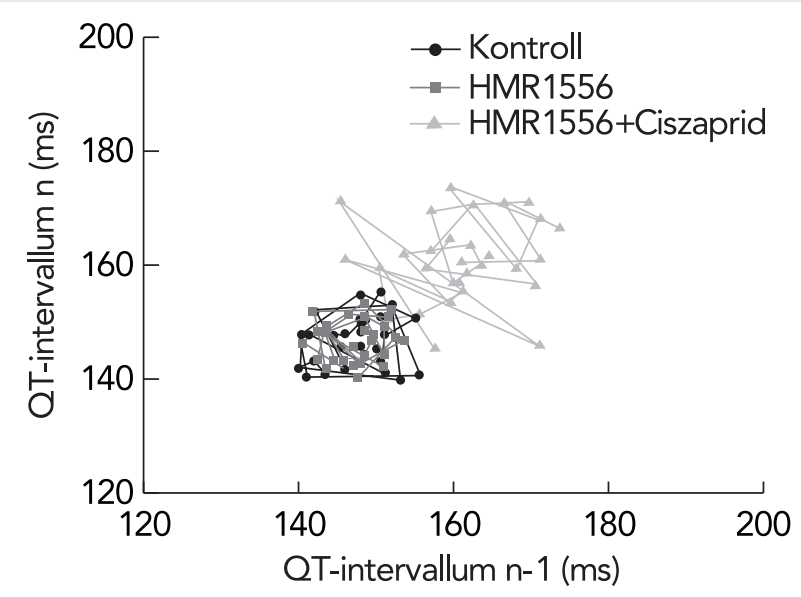

2. ÁBRA. Reprezentatív Poincaré-diagram, amely illusztrálja a QT-intervallum variabilitását az $\mathrm{I}_{\mathrm{Ks}}$-blokkoló HMR1556 (0,1 $\mathrm{mg} / \mathrm{kg})$ önmagában, és ciszapriddal $(0,5 \mathrm{mg} / \mathrm{kg})$ történt kombinált adagolását követően egy altatott nyúlon szignifikánsan emelkedett, legnagyobb mértékben a HMR1556 + 0,5 mg/kg ciszaprid kombinációt követően (3. ábra, jobb panel), mely kezelést követően alakult ki leggyakrabban a TdP-ritmuszavar (4. ábra, D-panel).

A kamrai ritmuszavarok gyakoriságát a 4. ábra foglal-

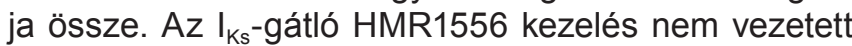
kamrai ritmuszavarok kialakulásához. A ciszaprid adagolás azonban változatos aritmiákat indukált altatott nyulakon. A HMR előkezeléstől függetlenül, az állatok túlnyomó többségében kialakultak kamrai extraszisztolék ciszaprid adagolást követően (4. ábra, A-panel). Az I I Ks -gátlás, hasonlóan a kamrai extraszisztolék esetén tapasztaltakhoz, nem befolyásolta szembetűnően a ciszaprid indukálta Salvo és kamrai tachycardia előfordulását (4. ábra, B-és $C$-panelek). Ezzel szemben, a ciszaprid indukálta TdP előfordulása az $\mathrm{I}_{\mathrm{Ks}}$-gátlást követően a ciszaprid legkisebb alkalmazott dózisának adagolását követően volt a leggyakoribb. Kiemelendő, hogy a kamrai aritmiák kialakulása előtt mért STV $\mathrm{QT}_{\text {-ér- }}$ ték ebben a csoportban volt a legmagasabb (3. ábra, jobb panel).

\section{Megbeszélés}

A gyógyszerjelöltek preklinikai, szív-elektrofiziológiai biztonsági vizsgálatára jelenleg használt módszerek a szívizom kamrai repolarizáció nyújtó mellékhatásra koncentrálnak $(4,5)$, ugyanakkor nem megbízhatóak, nem jelzik kellő érzékenységgel a vizsgált vegyületek proaritmiás mellékhatásait. A felhasznált in vitro és in vivo modellek egészséges szöveteket, állatokat alkalmaznak $(4,5)$, így nem képviselik megfelelően a ritmuszavarok kialakulására fokozottan érzé- 

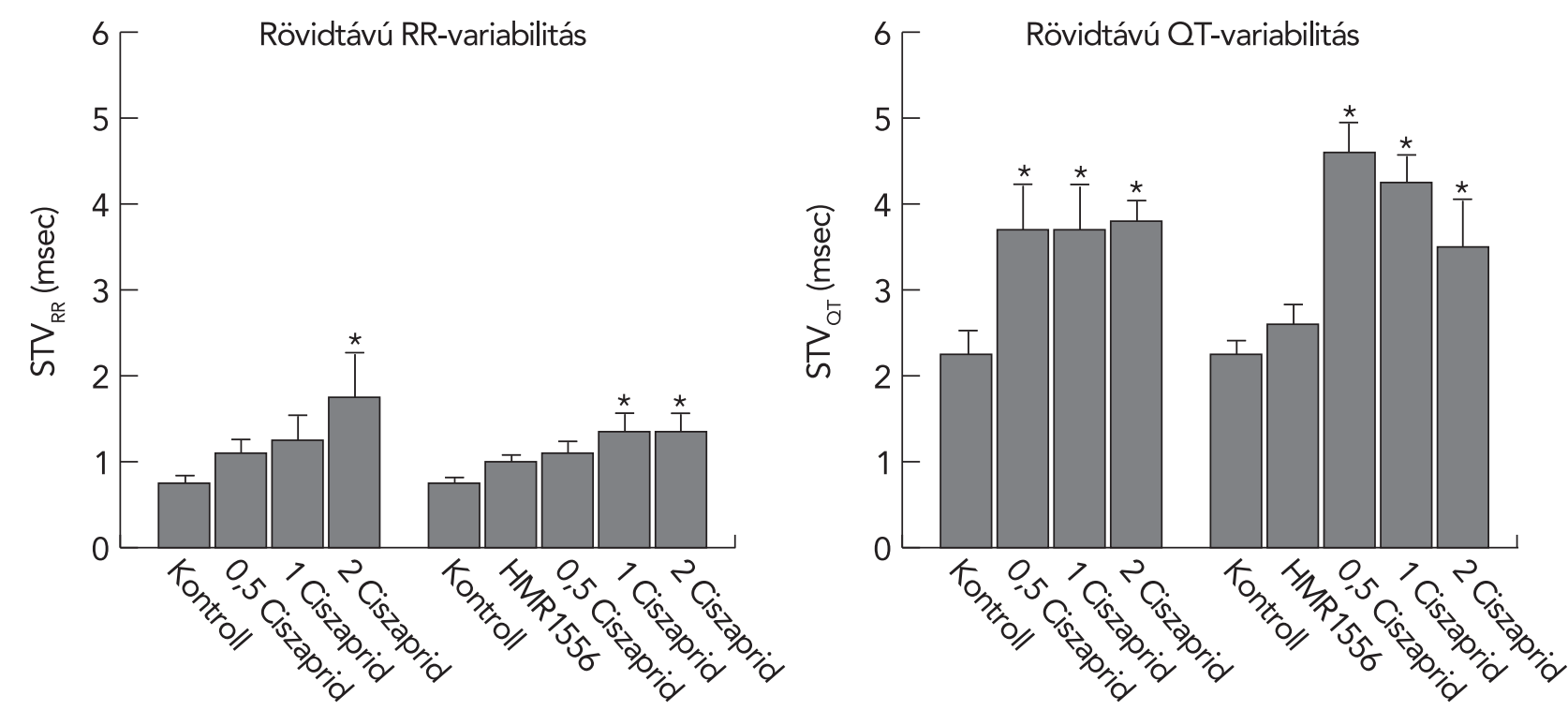

3. ÁBRA. Az RR- és QT-intervallumok rövidtávú variabilitása ciszaprid (0,5-1, és $2 \mathrm{mg} / \mathrm{kg})$, az $\mathrm{I}_{\mathrm{Ks}}$-gátló HM1556 $(0,1 \mathrm{mg} / \mathrm{kg})$ és kombinációjuk adagolását követően altatott nyulakon. $n=10$ mindkét csoportban; * $\mathrm{p}<0,05$ a kontrollhoz képest
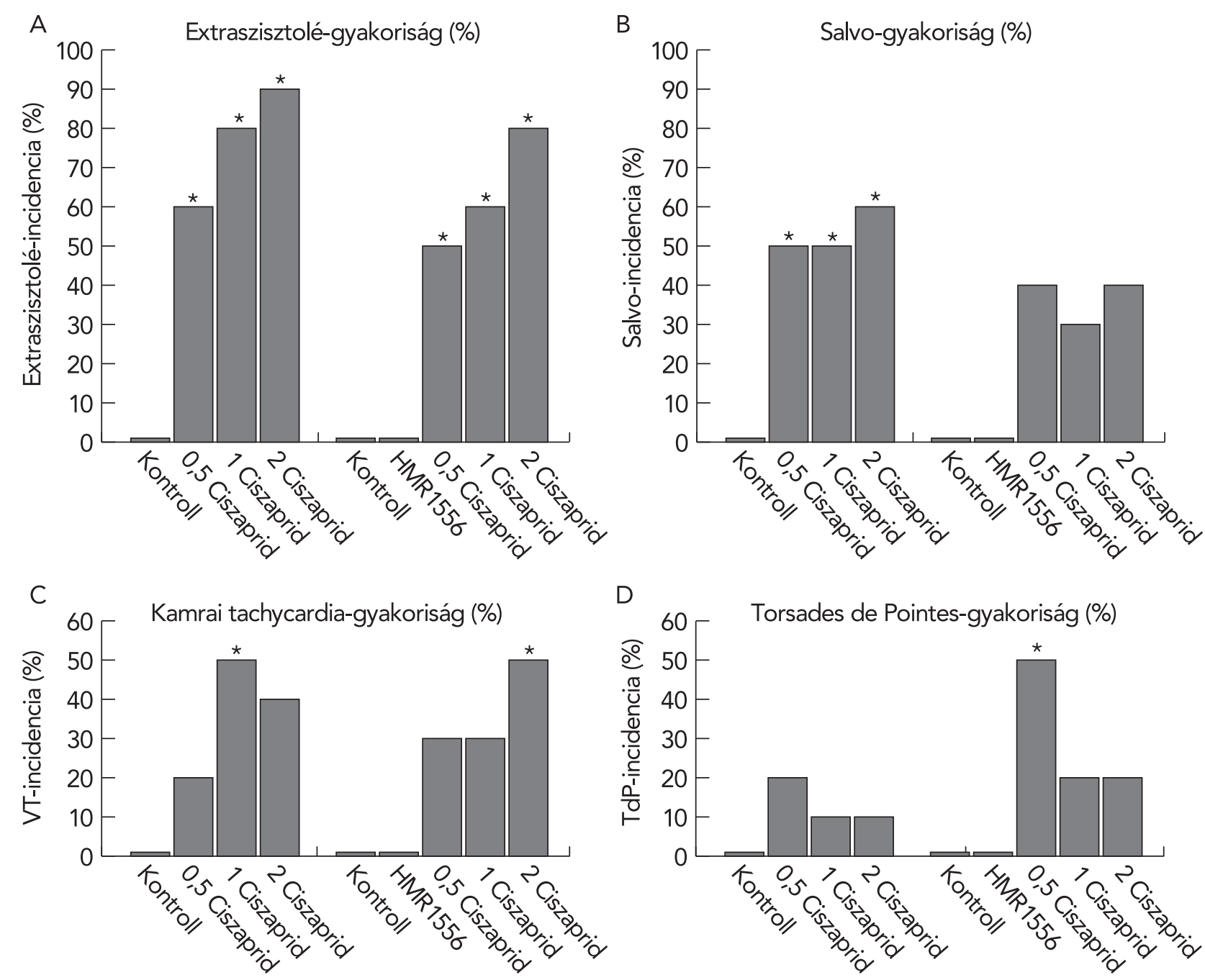

4. ÁBRA. Különféle kamrai ritmuszavarok előfordulási gyakorisága ciszaprid (0,5-1, és $2 \mathrm{mg} / \mathrm{kg})$, az I $\mathrm{ks}_{\mathrm{s}}$-gátló HM1556 (0,1 mg/kg) és kombinációjuk adagolását követően altatott nyulakon. $n=10$ mindkét csoportban; * $p<0,05$ a kontrollhoz képest 
keny betegpopulációkat (21); továbbá számos klinikai és állatkísérletes adat bizonyítja, hogy a repolarizáció megnyúlásának mértéke nem korrelál a súlyos ritmuszavarok kialakulásának gyakoriságával. Munkacsoportunk a korábbiakban két, a repolarizációs rezerv kialakításában kulcsszerepet játszó $\mathrm{I}_{\mathrm{Ks}}$-csatorna (13, 14) funkciójának csökkentésén alapuló, gyengített repolarizációs tartalékkal rendelkező (22) proaritmiás in vivo állatmodellt vezetett be $(15,23)$. Jelen tanulmányunkban a proaritmiás mellékhatásai miatt számos országban forgalomból kivont prokinetikum, a ciszaprid ritmuszavarokat kiváltó hatásait vizsgáltuk szükített repolarizációs tartalékkal jellemezhető nyúlmodellen. Eredményeink szerint a ciszaprid önmagában adagolva is okozott kamrai ritmuszavarokat, de a tipikus gyógyszer indukálta kamrai ritmuszavar, a Torsades de Pointes incidenciája csökkent repolarizációs tartalék mellett volt a legmagasabb. A legnagyobb TdP gyakoriság mellett számítottuk a legnagyobb mértékü rövidtávú $Q T$-intervallum variabilitás $\left(S T V_{Q T}\right)$ emelkedést, amely a súlyos kamrai ritmuszavarok megbízhatóbb előrejelzésére közelmúltban ajánlott helyettesítő EKG biomarker (24).

Jelen munkánkban a repolarizációs rezerv csökkentését az $\mathrm{I}_{\mathrm{Ks}}$ akut farmakológiai gátlásával értük el. Az erre a célra alkalmazott HMR1556 korábbi vizsgálatokban az $I_{\mathrm{Ks}}$ szelektív gátló szerének bizonyult $\left(\mathrm{IC}_{50}: 10-5-30\right.$ $\mu \mathrm{M})$ gátolta $(25,26)$. Jelen tanulmányunkban, hasonlóan korábbi eredményeinkhez (15), az $\mathrm{I}_{\mathrm{Ks}}$-gátló alkalmazott dózisa nem okozott az EKG-felvételen tetten érhető repolarizáció megnyúlást (1. ábra). In vivo proaritmiás modellünk jelen munkánkban kivitelezett további validálásához a proaritmiás vizsgálatokban használatos ciszapridot használtuk fel (27). A ciszaprid egy benzamid származék prokinetikum (28), amelyet TdP-t, palpitációkat, QT-intervallumot nyújtó mellékhatásai miatt számos országban kivontak a forgalomból (29, 30). A repolarizáció nyújtó hatást a ciszaprid hERG-áramgátló hatásának tulajdonítják (31). Jelen eredményeink szerint intakt repolarizációs tartalék mellett (1. csoport, csak ciszapriddal kezelt állatok) és szűkített repolarizációs rezerv mellett (2. csoport, HMR1556 előkezelt állatok) a ciszaprid hasonló mértékü $\mathrm{QT}_{\mathrm{c}}$-intervallum megnyúlást okozott (1. ábra). Ugyanakkor a repolarizációs tartalék $I_{\mathrm{ks}}$-gátlóval történt szűkítését követően alakult ki a legtöbb állatban gyógyszer indukálta TdP (4. ábra), és az STV ${ }_{\mathrm{QT}}$ a legtöbb TdP-t indukáló kezelés után (de a TdP megjelenése előtt) volt a legmagasabb (3. ábra). Ezen eredmények megerősítik a korábbi megfigyelést, miszerint a $\mathrm{QT}_{\mathrm{c}}$-intervallum megnyúlásának mértéke nem jelzi előre a kialakuló ritmuszavarokat, illetve azok súlyosságát. Ezzel szemben az STV $\mathrm{QT}_{\mathrm{T}}$ megbízhatóbban jelezte a súlyos kamrai aritmiák kialakulását mind állatkísérletes $(15,23,32,33)$, mind klinikai körülmények között $(34,35)$. Egy érdekes tanulmány szerint a ciszaprid szívelégtelen nyulakból izolált szíveken nagyobb mértékben fokozta a TdP előfordulását, mint egészséges nyulakból izolált szíveken (36). A szívelégtelenségben fellépő strukturális átépülés („remodelling”) mellett a szívelégtelen betegek fokozott ritmuszavar érzékenységéért felelőssé tett elektromos remodelling részeként az $\mathrm{I}_{\mathrm{Ks}}$-csatorna expressziójának jelentős csökkenését mutatták ki, amely így hozzájárul a repolarizációs tartalék csökkenéséhez a fenti betegeken (21). İgy a szívelégtelen nyúl a kamrai ritmuszavarok iránt érzékeny egyik betegpopulációt reprezentáló proaritmiás modellként jöhet szóba (36).

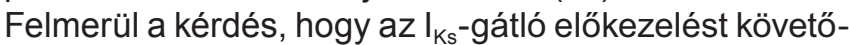
en miért csak a ciszaprid kisebb dózisa fokozta a TdP előfordulását, hiszen a nagyobb dózisok esetén az incidencia csak $20 \%$ volt jelen kísérleteinkben (4. ábra). Ismert, hogy a ciszaprid nagyobb dózisai a kisebb dózis mellett jelentkező $\mathrm{I}_{\mathrm{Kr}}$-gátló hatás mellett már más ionáramokat, így az L-típusú kalciumáramot $\left(\mathrm{I}_{\mathrm{Ca}, \mathrm{L}}\right)$ is gátolja (37). Az I $\mathrm{C}_{\mathrm{Ca}, \mathrm{L}}$-gátló szerei viszont alkalmasak a TdP megszüntetésére, míg az $\mathrm{I}_{\mathrm{Ca}, \mathrm{L}}$ inaktivációjának akadályozása jelentős proaritmiás hatáshoz vezet (38). Így feltehető, hogy nagyobb dózisban, amikor a ciszaprid több ioncsatornát gátló hatásai egyidejüleg álltak fenn, akkor a proaritmiás hatás mellett jelen kísérleteinkben „antiaritmiás” hatások is érvényesültek.

\section{Következtetések}

Jelen tanulmány szerint a repolarizációs tartalék létrehozásában kulcsszerepet játszó $\mathrm{I}_{\mathrm{Ks}}$-áram akut farmakológiai gátlása altatott nyulakon fokozza a kamrai ritmuszavarok iránti érzékenységet. Csökkent repolarizációs rezerv mellett ebben a modellben a proaritmiás mellékhatásai miatt gyógyszerforgalomból kivont ciszaprid fokozta a kamrai aritmiák, köztük a TdP előfordulási gyakoriságát, és a fokozott ritmuszavar incidenciát a QT-intervallum rövidtávú variabilitásának szignifikáns emelkedése előzte meg. Ennek megfelelően eredményeink támogatják a proaritmiás kockázat felmérésére során az $\mathrm{STV}_{\mathrm{QT}}$-paraméter meghatározását a hagyományos EKG-paraméterek tanulmányozásán felül.

\section{Köszönetnyilvánítás}

Jelen munka a Nemzeti Kutatási, Fejlesztési és Innovációs Hivatal (OTKA NN-110896, és GINOP-2.3.2-15-2016-00047), a Magyar Tudományos Akadémia támogatásával készült. Továbbá, a kutatás a TÁMOP 4.2.4.A/2-11-1-2012-0001 azonosító számú „Nemzeti Kiválóság Program - Hazai hallgatói, illetve kutatói személyi támogatást biztosító rendszer kidolgozása és müködtetése konvergencia program" címü kiemelt projekt keretei között valósult meg (B.I.). Megkülönböztetett köszönetünket szeretnénk kifejezni Papp Gyula akadémikus Úrnak, aki a jelen dolgozat szerzőinek pályáját messzemenően támogatta. 


\section{Irodalom}

1. Farkas A, Nattel S. Minimizing Repolarization-Related Proarrhythmic Risk in Drug Development and Clinical Practice. Drugs 2010; 70: 573-603. doi: 10.2165/11535230-000000000-00000

2. Haverkamp W, Breithardt G, Camm AJ, et al. The potential for QT prolongation and pro-arrhythmia by non-anti-arrhythmic drugs: clinical and regulatory implications. Report on a Policy Conference of the European Society of Cardiology. Cardiovasc Res 2000; 47: 219-233. doi: 10.1016/S0008-6363(00)00119-X

3. Fenichel RR, Malik M, Antzelevitch C, et al. Drug-induced torsades de pointes and implications for drug development. J. Cardiovasc Electrophysiol 2004; 15: 475-495. doi: 10.1046/j.15408167.2004.03534.x

4. ICH-S7B. International conference on harmonisation; guidance on S7B nonclinical evaluation of the potential for delayed ventricular repolarization (QT interval prolongation) by human pharmaceuticals; availability. Notes. Fed Regist 2005; 70: 61133-61134. PMID: 16237859

5. ICH-E14. International conference on harmonisation: guidance on E14 clinical evaluation of $Q T / Q T_{c}$ interval prolongation and proarrhythmic potential for non-antiarrhythmic drugs; availability. Notes. Fed Regist 2005; 70: 61134-61135. PMID: 16237860

6. Varró A, Baczkó I. Cardiac ventricular repolarization reserve: principle for understanding drug-related proarrhythmic risk. $\mathrm{Br}$ Pharmacol 2011; 164: 14-36. doi: 10.1111/j.1476-5381.2011.01367.x 7. Mattioni TA, Zheutlin TA, Sarmiento JJ et al. Amiodarone in patients with previous drug-mediated torsade de pointes. Long-term safety and efficacy. Ann. Intern Med. 1989; 111: 574-580. doi 10.7326/0003-4819-111-7-574

8. Hondeghem LM, Carlsson L, Duker G. Instability and triangulation of the action potential predict serious proarrhythmia, but action potential duration prolongation is antiarrhythmic. Circulation 2001; 103 2004-2013, doi: 10.1161/01.CIR.103.15.2004

9. van Opstal JM, Schoenmakers M, Verduyn SC, et al. Chronic amiodarone evokes no torsade de pointes arrhythmias despite QT lengthening in an animal model of acquired long-QT syndrome. Circulation 2001: 104: 2722-2727. doi: 10.1161/hc4701.099579

10. Belardinelli L, Antzelevitch C, Vos MA. Assessing predictors of drug induced torsade de pointes. Trends Pharmacol Sci 2003; 24 619-625. doi: 10.1016/j.tips.2003.10.002

11. Akar FG, Spragg DD, Tunin RS, et al. Mechanisms underlying conduction slowing and arrhythmogenesis in nonischemic dilated cardiomyopathy. Circ Res 2004; 95: 717-725. doi: 10.1161/01. RES.0000144125.61927.1c

12. Roden DM. Taking the idio out of idiosyncratic - predicting torsades de pointes. Pacing Clin Electrophysiol 1998; 21: 1029-1034. doi: 10.1111/j.1540-8159.1998.tb00148.x

13. Varró A, Baláti $B$, lost $N$, et al. The role of the delayed rectifier component $\mathrm{I}_{\mathrm{Ks}}$ in dog ventricular muscle and Purkinje fibre repolarization J Physiol 2000; 523: 67-81. doi: 10.1111/j.1469-7793.2000.00067.x 14. Jost $\mathrm{N}$, Virág L, Bitay $\mathrm{M}$, et al. Restricting excessive cardiac action potential and QT prolongation: a vital role for $\mathrm{I}_{\mathrm{Ks}}$ in human ventricular muscle. Circulation 2005; 112: 1392-1399. doi: 10.1161/CIRCULATIONAHA.105.550111

15. Lengyel $C$, Varró $A$, Tábori $K$, et al. Combined pharmacologica block of $\mathrm{I}_{\mathrm{Kr}}$ and $\mathrm{I}_{\mathrm{Ks}}$ increases short-term QT interval variability and provokes torsades de pointes. Br J Pharmacol 2007; 151: 941-951. doi: 10.1038/sj.bjp.0707297

16. Thomsen MB. Double pharmacological challenge on repolarization opens new avenues for drug safety research. Br J Pharmacol 2007; 151: 909-911. doi: 10.1038/sj.bjp.0707299

17. Farkas A, Batey AJ, Coker SJ. How to measure electrocardiog raphic QT interval in the anaesthetized rabbit. J Pharmacol Toxicol Methods 2004; 50: 175-185. doi: 10.1016/j.vascn.2004.05.002

18. Batey AJ, Coker SJ. Proarrhythmic potential of halofantrine, terfenadine and clofilium in a modified in vivo model of torsade de pointes. Br J Pharmacol 2002; 135: 1003-1012. doi: 10.1038/sj.bjp.0704550 19. Curtis MJ, Hancox JC, Farkas A, et al. The Lambeth Conventions (II): guidelines for the study of animal and human ventricular and supraventricular arrhythmias. Pharmacol Ther 2013; 139: 213248. doi: 10.1016/j.pharmthera.2013.04.008
20. Brennan $M$, Palaniswami $M$, Kamen $P$. Do existing measures of Poincaré plot geometry reflect nonlinear features of heart rate variability? IEEE Trans Biomed Eng 2001; 48: 1342-1347. doi: 10.1109/10.959330

21. Nattel S, Maguy $A$, Le Bouter $S$, et al. Arrhythmogenic ion channel remodeling in the heart: heart failure, myocardial infarction, and atrial fibrillation. Physiol Rev 2007; 87: 425-456. doi: 10.1152/physrev.00014.2006

22. Baczkó I, Jost N, Virág L, et al. Rabbit models as tools for preclinical cardiac electrophysiological safety testing: Importance of repolarization reserve. Prog Biophys Mol Biol 2016; 121: 157-168. doi: 10.1016/j.pbiomolbio.2016.05.002

23. Major $\mathrm{P}$, Baczkó I, Hiripi L, et al. A novel transgenic rabbit model with reduced repolarization reserve: long QT syndrome caused by a dominantnegative mutation of KCNE1 gene. Br J Pharmacol 2016; 173: 2046-2061. doi: 10.1111/bph.13500

24. Varkevisser R, Wijers SC, van der Heyden MA, et al. Beat-tobeat variability of repolarization as a new biomarker for proarrhythmia in vivo. Heart Rhythm 2012; 9: 1718-1726. doi: 10.1016/j.hrthm.2012.05.016

25. Gögelein H, Bruggemann A, Gerlach U, et al. Inhibition of IKs channels by HMR 1556. Naunyn Schmiedebergs Arch Pharmacol 2000; 362: 480-488. doi: 10.1007/s002100000284

26. Thomas GP, Gerlach U, Antzelevitch C. HMR 1556, a potent and selective blocker of slowly activating delayed rectifier potassium current. J Cardiovasc Pharmacol 2003; 41: 140-147. doi: 10.1097/00005344-200301000-00018

27. Yamamoto $W$, Asakura $K$, Ando $H$, et al. Electrophysiological Characteristics of Human iPSC-Derived Cardiomyocytes for the Assessment of Drug-Induced Proarrhythmic Potential. PLoS One 2016; 11: e0167348. doi: 10.1371/journal.pone.0167348

28. Reboa G, Arnulfo G, Frascio M, et al. Colon motility and colo-anal reflexes in chronic idiopathic constipation. Effects of a nove enterokinetic agent cisapride. Eur J Pharmacol 1984; 26: 745-748. doi: 10.1007/BF00541936

29. Wysowski DK, Bacsanyi J. Cisapride and fatal arrhythmia. N Eng J Med. 1996; 335: 290-291, doi: 10.1056/NEJM199607253350416 30. Hennessy S, Leonard CE, Newcomb C et al. Cisapride and ventricular arrhythmia. $\mathrm{Br} \mathrm{J}$ Clin Pharmacol 2008; 66: 375-385. doi: 10.1111/j.1365-2125.2008.03249.x

31. Mohammad S, Zhou Z, Gong Q, et al. Blockage of the HERG human cardiac $\mathrm{K}+$-channel by the gastrointestinal prokinetic agent cisapride. Am J Physiol Heart Circ Physiol 1997; 273: H2534-2538. PMID: 9374794

32. Thomsen MB, Verduyn SC, Stengl M et al. Increased short-term variability of repolarization predicts $\mathrm{d}$-sotalol-induced torsades de pointes in dogs. Circulation 2004; 110: 2453-2459. doi: 10.1161/01. CIR.0000145162.64183.C8

33. Husti Z, Tábori K, Juhász V et al. 2015. Combined inhibition of key potassium currents has different effects on cardiac repolarization reserve and arrhythmia susceptibility in dogs and rabbits. Can J Physiol Pharmacol 2015; 93: 535-544. doi: 10.1139/cjpp-2014-0514 34. Hinterseer M, Beckmann BM, Thomsen MB, et al. Relation of increased short-term variability of QTinterval to congenital long-QT syndrome. Am J Cardiol 2009; 103: 1244-1248. doi: 10.1016/j.amjcard.2009.01.011

35. Hinterseer M, Beckmann BM, Thomsen MB, et al. Usefulness of short-term variability of QT intervals as a predictor for electrical remodeling and proarrhythmia in patients with nonischemic heart failure. Am J Cardiol 2010; 106: 216-220. doi: 10.1016/j.amjcard.2010.02.033

36. Kijtawornrat A, Nishijima $Y$, Roche BM, et al. Use of a failing rabbit heart as a model to predict torsadogenicity. Toxicol Sci 2006; 93 205-212. doi: 10.1093/toxsci/kfl025

37. Chiang CE, Wang TM, Luk HN. Inhibition of L-type $\mathrm{Ca}^{2+}$ current in Guinea pig ventricular myocytes by cisapride. J Biomed Sci 2004; 11: 303-314. doi: 10.1159/000077098

38. Kim JG, Sung DJ, Kim HJ, et al. Impaired Inactivation of L-Type $\mathrm{Ca}^{2+}$ Current as a Potential Mechanism for Variable Arrhythmogenic Liability of HERG K+ Channel Blocking Drugs. PLoS One 2016; 11: e0149198. doi: 10.1371/journal.pone.0149198 